\title{
Religious Radicalism and Pluralism: The Conflict Between Religious People and Relation of Power Industry in Bekasi
}

\author{
Aden Rosadi ${ }^{1}$ \\ ${ }^{1}$ Lecture of the Faculty of Syariah and Law \\ State Islamic University of Sunan Gunung Djati Bandung, Indonesia \\ Email: adenrosadi@yahoo.com \\ Accepted Article: 29 October 2014 \\ Published Article: 20 April 2015
}

\begin{abstract}
Based on category, this program leads to three social issues. First, public awareness about the significance of the view of life that is more tolerant, open and more pluralis amid development of industrialization. Industrialization that developed in centers of growth (growth poles), which prominently still holdsrural-agrarian values, has given rise to what is called the proletarian farmers. "Proletarisation" was preceded by transition process of the function of farmland into industrial land, thus causing economic activity became more intense and integrated into industrial capitalism. This leads to the occurrence of an identity crisis that led to theopposition attitude in most communities, especially those who associated with the existence of other religions. Second, these changes have an impact on the emergence of community with radical attitude by carrying the religious themes. The construction of houses of worship, which is actually the "House of God" for any religions, considering the dangers may threaten the existence of the community and other faiths. The value system was formed, as a society oppressed became one of the motivators and catalysts for the inception of religious radicalism at the low level community. Third, the Government's policy regarding the construction of a harmony is among believers. This last part is related to the concept of good governance. As an institutional approach, the concept of good governance (good governance) is defined as the interaction between the organizers of the State (Government) and groups in the community. According to the World Bank, there are at least four important dimensions of good governance, i.e. example, effective legal framework, information that is in line with the transparency (accountability or Government) and the availability of welleducated workforce. In this context, the position of District Government of Bekasi becomes one of the institutions, which is responsible for the running of the relationship between the Government, employers or investors, religious figures, and the public as the three interest groups that cannot be separated in developing awareness of pluralism in religious life in the community.
\end{abstract}

Keywords: Radicalism, Pluralism, Religious people, Power industry

\section{A. INTRODUCTION}

Religious radicalism and pluralism were two mutually contradictory paradigms in religious life, other than in political, social, economic and cultural areas; because both are also referred to binary opposition, the two things are also difficult to be discussed and separated in the religious life. On the one hand, radicalism based on the paradigm is exclusive to exclude others (the other), 
rigid, closed, extreme and uncommon militarist, while pluralism puts forward a paradigm based on values of humanity, openness and inclusiveness ${ }^{1}$.

Therefore, discussing the issue of harmony among believers, as implementation of pluralism, means a direction or assumes the existence of a probability of a variety of faiths met in a common ground (common platform). Because the logic of harmony and tolerance is the attitude of mutual understanding and appreciation, which in sequences is to contain the logic of the intersection, though of course only to principle matters. Detailed things such as symbolic and formalistic expressions and are naturally hard to be reunited. Each religion, even each internal group a religion itself, which has a distinction and idiom, is esoteric, namely; "only applied internally". Therefore, meddling in an adherent of a religion in the sense of the sanctity of a person's problems from another religion is irrational and absurd.

Pluralism, harmony and religious tolerance are not foreign things for the community of the District of Bekasi. Coexistent non-Muslim groups, particularly ethnic Chinese Confucianism, Buddhism and Hinduism, have been running since hundreds of years ago; ancient temples and villages of China - such as Chinese town - also became witness to the history of how the religious life has been running harmoniously in this area. The religious tradition of ethnic Betawi - Banten, which is passed down, is still held although the current conditions are confronted with the complexities of modern life, lifestyle and negative infiltration of foreign culture are a potential and strength in maintaining and developing the spiritual life of the society. Religious traditions such as routine recitation majelis ta'lim, religious discourses, tahlil, shalawat and ratiban, remain held as religious values that have been running for a long time. Even today, the traditionally-institutionalized religious education in boarding schools still exist which totaled 41 boarding schools, 330 priests and 15.768 students.

With population about 2.270.900 people, since a couple of years of the District of Bekasi continues to develop and promote itself as an industrial area. In 2001, for example, with a total of 595 companies engaged in all fields, Current BekasiDistrict is the largest industrial area in Indonesia which is capable of absorbing labors from various regions in the amount of 666580 labor $^{2}$. Since the 1980s the progress of industrialization that is thriving in the District of Bekasi became a new chapter in the history of the society that still holds strong norms and tradition of an agrarian society. To sustain and accelerate vision the industry as a religious area, "Community-Based on religious Agribusiness and Sustainable Economy", Bekasi District currently has three regional industry giants that are scattered in the south, EJIP (East Jakarta Industrial Park), Jababeka, and Regions Cibitung industry 2100 . Not to mention the small areas other industries, most of which lies on the outskirts of the city. This growth, of course, spawned a wave of very large jobs that can absorb people from all over Indonesia who want to venture in this area. Briefly, the economic growth also increased quite rapidly until it reaches the Gross Regional Domestic Product (GRDP) amounted to 32,28 billion in 2001 with the largest contribution in the industrial sector amounted to $83,48 \%$.

\footnotetext{
1The paradigm of violence is often used differently in accordance with the interests that each carried, yet still has the same meaning. It can be referred to "Puritanism", "nativism", "extremism", "fanaticism", "militanisme" and others. See in Radikalisme Agama p. Xvi (Effendi \& Prasetyo, 1998).

2The effort field consisting of mining, industry, electricity, gas, water supply, building and construction, trade, hotels, restaurants, transport and communications, finance, leasing and services company. The Central Bureau of statistics (BPS) District of Bekasi in 2001 (Badan Pusat Statistik (BPS) Kabupaten Bekasi, 2001)
} 
Along with the development of industrialization, social-psychological symptoms as a result of the very rapid changes can be manipulated easily for specific purposes. It can cause these symptoms themselves automatically followed by feelings of disappointment, resentment, and an emotional desire to fight against the establishment. Establishment here is usually analogous to the Government and the ruling elite group (the ruling elite) (Munawar-Rachman, 2006). Even in view of Morris Janowitz, the impact of social change is the existence of prejudice or stereotype, which tends to be destructive and filled with the stigma of a particular group or groups, making it difficult to support the process of positive social change towards democracy and pluralism (MunawarRachman, 2006). Anthropologically, society of Bekasi District itself, which actually borrows a term Alvin Toffler-society of Bekasi, is a society that is still in two waves (wave) first civilization of mankind, namely agriculture and industry. Geographically, North Bekasi community is a living as farmers, that edged far behind its construction with the southern region as a center of industrialization, while the area of southern part is an industrial area which is considered to be the community's water absorption area of northern communities (Badan Pusat Statistik (BPS) Kabupaten Bekasi, 2001). The issue is getting complex due to not building the order value as industrial society or modern for most Bekasi people. It means that the construction physically cannot be followed by the development of their worldview, which is still very traditional. Modernization or industrialization occurs only on physical buildings, while awareness and worldview as traditional communities which have mystical, religious, Paguyuban (association) characteristic, and the spirit of patron-client are strong, each of it is held as the consciousness of life.

In this connection, there are some interesting frameworks to be explored as a social analysis of the problem of radicalism. Prof. Dr. Usman Pelly, a former professor of Anthropology IKIP Medan, suggests the existence of three sources of conflict in society. First, the scramble is for resources, production tools and economic opportunities; second, the expansion of the boundaries of ethnic and socio-cultural groups; and third, the clash of political interests, ideology and religion. Three of them more found in urban society or diverse society, which began to grow because of rapid industrial development compared to rural communities. Conflict intensity with the community diversity factors can be classified into two categories, namely horizontal and vertical. Horizontal factors include ethnic / racial origin or ancestry; regional language; mores; religion and sociopolitical life (Mulyana, 2000). If the horizontal diversity is ascribed to factors, whereas factors are vertical diversity characterized more by achievement factors. Those problems led to the public awareness as oppressed society. Oppressed by the globalization progress, that manifests itself in the form of industrial hegemony that is lack of attention to aspects of society and more concerned ethnic locality and a particular religion. It seems that people's prejudice or suspicion in industrialized peak when Jababeka management built a house of worship for Christians, church development in some elite residential complexes like Lippo city Cikarang, Perumahan Legenda in North Tambun. Instead, in some housing, the majority of which is Non-Muslims, the mosques and the small mosques were getting the same resistance. In this context, it seems quite relevant when Kuntowijoyo said that people who worked in the industrial sector or non-agricultural sector was in issue, such as unemployment or insult, it is easy to become emotionally aggressive, collective behavior has to be mobilized without any third party or fanned (Mulyana, 2000).

The shapesof idea containing the concept of radicalism can be applied to see the growing symptoms of social radicalism in Bekasidistrict last five years. As weltanshauung or worldview as well as life experiences (lebensew/t), religious radicalism that emerged from the denial of construction of houses of worship appears as the impact of developmentalism (developmentalism) or unfinished modernization in poor countries. Factor in the marginalization of the indigenous population in responding and the weak local governments as well as foreign and domestic 
investors, which are lack of maximum attention on community development, is the factors that lead to the rise of religious radicalism in the attitude of these industry areas.

\section{B. METHODS}

To uncover these problems, this research is more likely to use field research with a qualitative approach. This approach was chosen in addition to the effort to uncover the phenomenon of religious violence whose impact on social life-social, as well as religion is a problem that is more interpretive. Therefore, data collection is needed, both primary data and secondary data in the field.

The primary data consist of the papers written by the Muslim intellectualand journalistic reports (mass media) that were published about the patterns of religious radicalism in the Bekasi Regency area among the public. While secondary data include structured interview and now spread about the relationship between religious radicalism and the policy of the Government, employers and the society.

In a sampling of this questionnaire, the researcher will use multistage random sampling technique. The first phase will be for the population of Bekasi strata on the basis of population in each district throughout the Bekasi district in order to obtain samples in a proportionate amount in each district. All districts in Bekasi will be netted in this questionnaire. The second is the distribution of strata on the basis of area of residence: rural or city, which account for between $60 \%$ (city) versus $40 \%$ (rural). In addition, the strata are also done on the basis of the proportion of the population according to gender difference: $50 \%$ of men, and $50 \%$ of women.

The second phase is to determine village or equivalent as the primary sampling unit (PSU), and because it was conducted on a systematic random villagers / kelurahaanin each district according to the level of conflict. In each village then listed the names of the Neighborhood (RT), and then selected at random by $5 \mathrm{RT}$. In each selected RT 2 family then selected at random. The 2 families that are selected list family members of men and women between the ages of 17-60 years. When the first families to be elected to the respondents were female, then the second family in the same RT should list men.

Sampling process can be described as follows:

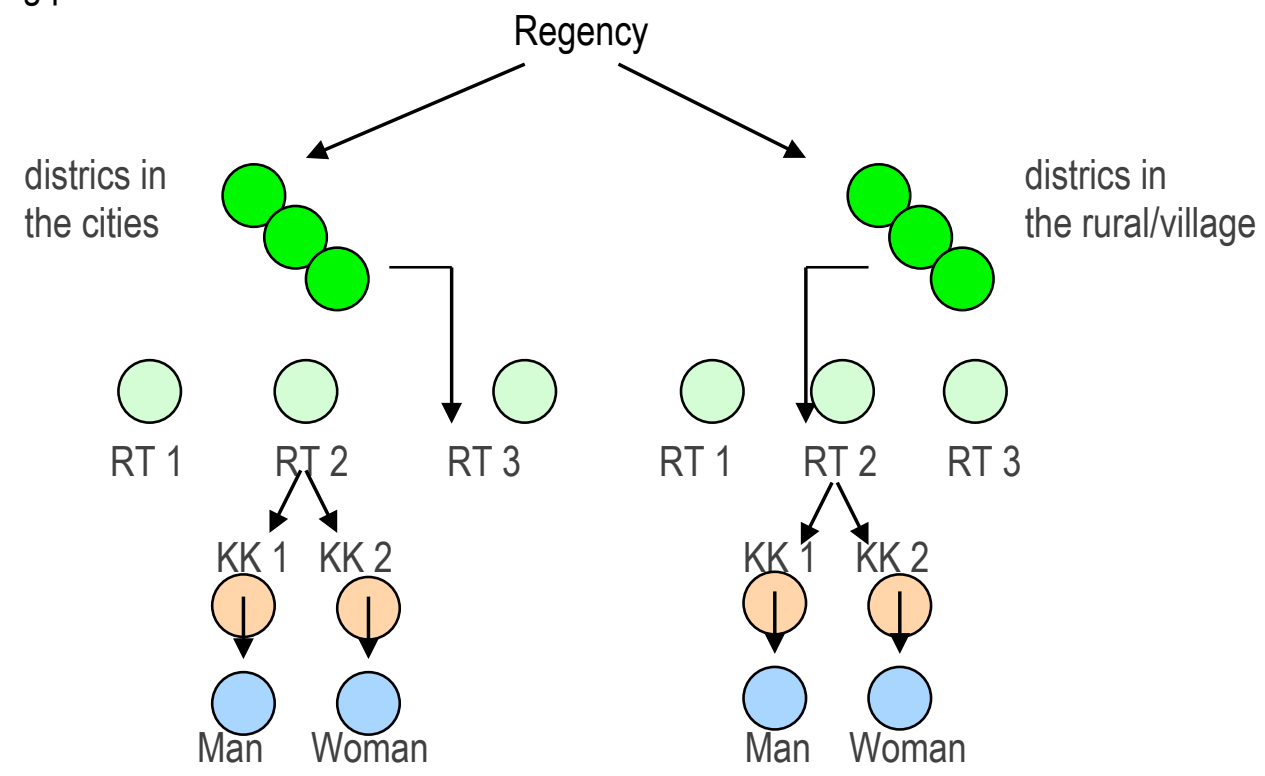


The main data of this research come from the results of structured interviews using indicators, such as (a) the development of government policy regarding the values of pluralism and interreligious concord, (b) the role of entrepreneurs in developing industrialization based on the values of pluralist; (c) religious radicalism which covers the history of its emergence, patterns and agenda of struggle and response to the regime and businessmen. The sample in this research is the head of the region, institutions or business associations, religious leaders of Islam and Christianity, Islamic organizations and community leaders.

After the data are collected, the interpretation process is performed by using a model-historical interpretation of phenomenology, which interprets the data as it is in the context of the development of society without trying to reduce or justify researchers' subjectivity. Therefore, to support and obtain the expected data which, used a qualitative approach are pluralist paradigmdialogue, whose approach is regarded as an important dialogue in pluralism, even a necessity. This approach appreciates and puts others from a personal perspective, and puts themselves in the presence of others. Therefore, approaching the relationship among religions as dialogue means approaching from below, which from religion as a social phenomenon as a religious community ${ }^{3}$. This authentic dialogue is clearly illustrated by aphilosopher Jacques Maritain, "The Culmination of knowledge is not conceptual but experiential man / woman 'feel' God'. The explanation of all according to the facts, appreciation of the running dynamics, deeply dig soul of the people, they experience and explore their motivation in neutral without the benefit of power, all these things will be very helpful to understand the phenomenon of violence in the contemporary Muslim world (Hanafi, 2001).

Handling of radicalism and pluralism is embodied in the resistance of construction this house of worship, which is geared to help the community and the Government in developing a civil society. Thus, the purposes of this research are expected for:

a. To reveal the process of religious radicalism, browse through the associated actors as well as the relation's interests, and uncover the social impact in the social-religious life of the society. EWTProvide objective information and data to the scientific community and the Government regarding issues of religious radicalism that manifests in the denial of the construction of houses of worship in some areas in Bekasi District.

b. To disassemble and unravel the veil as the real problem are the main problem that branch out in Bekasi industrial society.

c. To push vertices society to engage in the process of building a shared awareness about the importance of coexistence among people with different faiths.

The benefits of the program are:

a. Unfolding the relationship of religious radicalism in the context of changing industrial society with issues of poverty, unemployment, and economic equity as well as the factors and actors that are interested in-group plays. In addition, this research provides data and information that are objective, scientifically valid and concerning radicalism and tolerance of religious people life in the District of Bekasi.

b. Revealing structure and ideological radicalism developing in society. 
Growing awareness among the public, religionist and government about the actual substance of the issues underlying the emergence ofconstruction rejection for the house of worship in the form of religious radicalism.

\section{RESULT AND DISCUSSION}

Problems concerning the phenomenon of religious radicalism is not a new discourse for most people. Numerous works have been born just to discuss this issue, both through books, journals, magazines and newspapers. By Bahtiar Effendi and Hendro Prasetyo, entitled Religious Radicalism (Effendi \& Prasetyo, 1998), gives an overview ofviolent social-religious phenomenon formed by national interests and internationalization. Globalization was giving a negative impact through the internalization of the values of the violence and ideology war that occurs in the middle of the community. Hence in this book, the violence is regarded as a globalscale and regional phenomena.

Islamic Post - new order describing the radicalism of religion and the collapse of pluralism values in the reform era as diversity problems is very complex post-New Order. The riots with nuance of SARA (ethnic, religious, racial and intergroup) after the new order based on a lot of different factors withdraw religion into the conflict. Call it due to economic and political interests at both the elite and the masses. Suppose ethnic Madurese in Kalimantan who have lived for generations in these areas. They mastered the trade sector. This condition reduces the natives' business opportunitiesin that area. Hence the effort was developed by indigenous communities like expelling them from that area.It was the trigger social conflict (Tebba, 2001). Another factor is the seizure of Government driven by the implementation of the regional act of autonomy (act No. 22 of 1999 on local governance) that authorize each region to set up their own household. As a result of social groups with different interests attempted to seize the power that was abandoned by the Central Government (Tebba, 2001).

It seems that Komaruddin Hidayat knows more about the symptoms of religious radicalism, which were more psychological-sociological as political consequences and religion which do not run properly. The feelings felt "marginalized", "oppressed", are not taken into account politically even regarded as a "burden" or "buggers" of development are the main source of conflict that resulted in an attitude of religious radicalism (Hidayat, 1998). When some people with latent interests (unconscious) of the same mutually chatted, then their interests often emerge into consciousness. The same aspiration is then turned into the norm group, and ownership of such aspirations becomes a manifestation of loyalty towards the group. The result can be called as a camp group or group of fighters (Pruitt \& Rubin, 2004).

Dahrendorf mentions three conditions that favor the emergence of camp group and often the impetus for the onset of the conflict, namely (1) constant communication among good people;(2) the presence of a leader who helped articulate ideology, organize groups, and formulate a plan of action for the group, and (3) the Group legitimacy in the point of view of the wider community - or at least there is no community's pressure that is effective to groups(Pruitt \& Rubin, 2004).

However, a discussion of religious radicalism in the more specific contextstill seems to be less. Moreover, religious radicalism as the impact of the economic problems that affected the denial of construction of houses of worship in certain areas might almost be saidthat it does not exist yet. To that end, almost be said that research on the problem of religious radicalism and pluralism in Bekasi District just has a few references to the theoretical literature and general theoretical. 
Therefore, to support the referral source, researchers tried to take and process from a variety of sources related to this research theme.

Hans King has said that true religion would not be contrary to human values, since religion has always defended and respected them (Sarapung, Agoeng, \& Jogoena, 1993). Such assumptions are correct in seeing the transcendental message of religion that carries the prophetic message upholding human values (humanity/insâniyyat), such as justice ('adl/justice), equal rights and position in front of the law (equality/musâwah), Liberation (freedom/hurriyyah), peace (salâm/ peace) and live the mutual respect of one another (tasammuh). Even teaching to respect ethnic and religious differences of others as human nature for us to compete in the goodness of the earth is revealed in one of his words (Surat Al-Mâ'idah [5] 48). This is that called integrative potential religion if it has become my Weltanschauung, it could participate in the process of changing society through industrialization. However, if the dimensions of the immanence or historical religion turns to have the potential of disintegratif in addition to the fields of politics, economy and the orientation of the tribe. Not a few of these dimensions into the dark history of all religions-lslam, Christianity, Hinduism and Buddhism. In fact, this condition is happening in almost every religion, Indonesian Muslims in General and Bekasi Muslims in particular.

Philosophically, the phenomenon of religious radicalism and pluralism is an issue related to the experience of the core (core experience), a collective memory (collective memory) and interpretation (interpretation) religion (Banawiratma, 1993). Pluriformity of life, ethnicity, tribe and religion is a principle that is primordial sunnatullah, which could not have been avoided by anyoneactiveor passive. Its existence is the core experience of all religions that teach the existence of others in this life. But the core of the primordial nature experience - this divine life in space history that forms the collective memory or experience of life in the religious life. Psychologically, the collective memory of religion varies according to time and space; it can be positive or negative, too. Both have very different implications in doing the interpretation of religious teachings. Religious communities that are being on the crest of success will be different from the religious community who are in the marginalized position in interpreting the content that contains the religions. In the end, radicalism and tolerance in religious life can take a variety of forms, such as orientation andpolitical, economic, social and even cultural objectives. The case of religious radicalism and pluralism, which occurred in Bekasi District, is an illustration of religion as a core experience (core-experience) that should be my Weltanschauung and can become a community of adhesive, which is undergoing an industrial revolution. However, economic and political oppression that afflicts the majority of the indigenous community, which is actually a Muslim majority, this core experience is also replaced with collective memory and religious interpretations that tend to be radicalism. Thus, do not be surprised if the Muslim community is often cited as a barrier and a troublemaker for the government and the owners of capital to accelerate development in all fields.

Industrialization was given a definition as a process of technological developmentthrough the use of applied science. It is characterized by a massive production expansion through the use of power machinery, extensive marketing area for goods producers as well as consumers, employees and professional Division of labor, and increasing urbanization (Munawar-Rachman, 2006).

Accompanying the changes in the economic sphere is a complex change in groups and social process. The first stage in the process of industrialization, a typical side by side with urbanization, is the increasing mobility of the population, in addition to the presence of important changes in the custom with the ability and moral society. But the thing that really stood out was the influences of 
employment status and skills of resident's work, family life and the position of women, as well as the traditionwith the ability in consuming the goods. Conflicts between classes, races, religions and other social groups are also seen as a result of the typical Companion.

Thus, industrialization is related to social change, ie the change of social structure social system pre-industrial (agricultural) to industrial social system. Sometimes it is also aligned with the change from pre-modern society to modern society. Or, in terms that are often used today, the change from "less developed countries" (less developed country) to the state of society "more developed countries" (more developed countries). To that end, social scientists distinguish relations "natural and organist" families, villages, and small towns (gemeinschaft) with the condition that is "artificial" and "isolated" from the city life and industrial society (gesellschaft), when the relationof nativeand natural humans with each other has been ruled out, and everyone fought for their own benefit in a spirit of competition. According Bahtiar Effendi, meeting (encounters) religious community with empirical reality does not always take the form of a constructive dialogic discourse. Instead, which appear are the dread myths that formed the impression that the rapid social change causing of religion is in the bottom position (subordinate) or "edge". An experience of Western European society, which is in the view of Ernest Gellner, "meeting" them with the development of the social sciences and industrialization deliver them at the door "secularization". With that, the values of religious concern faded (Effendi \& Prasetyo, 2000).

Even up to a certain level, the religious community is confronted with the situation of Vertigo in the face of the process of globalization. The worries that technological developments can be (a) marginalizing the religious values; (b) destroy the bonds of social units society; and (c) ultimately separates religion from the bases of its organization (Effendi \& Prasetyo, 2000). This is the value system of compensation of negative community attitudes that gave raise to the religious radicalism among the public.

The term "radicalism" is not a foreign concept in the social sciences. The disciplines of politics, sociology, and history have long been using the term to describe a particular social phenomenon. Historian Kartodirjo Kartono, for example, uses the term to describe the protest movements of farmers who use the symbol of religion in decline all over the rules and the existing order. The word "radical" is used as an indicator of the total refusal attitude against an ongoing condition (Effendi \& Prasetyo, 1998). In this context, Adeed Dawisha describes radicalismas stance that leads tothe steps that are referred to weaken and change stable political order, usually with violence and replace it with new system 4 .

Adopting the findings of Horace m. Kallen, social radicalism has at least three characteristics in doing the mainstream movement. First, radicalism is a response to the ongoing condition. Usually the response came in the form of evaluation, rejection or even resistance. The problems that were rejected in the form of assumptions, ideas, institutions, or values that are considered responsible for the continuity of the conditions, which was rejected. Second, radicalism did not come to a halt at the refusal, but rather is constantly working to replace the order with another order form. These characteristics suggest that the radicalism embody the program or its own view of the world. Thus, in accordance with the meaning of the word "Radic", it contains radical stance desire to change things fundamentally. Third, the latter characteristic is the strong conviction of the truth of the

${ }^{4}$ According Adeed Davisha, no essential difference between "terrorism" and "radicalism". If "terrorism" is only one among a variety of policy instruments offenders, being "radicalism" is the essence of the policy itself; radicalism also includes the values, goals and concerns of the people who formulate these policies. See Dr. Azyumardi Azra p. 147 (Azra, 1996). 
radical program or ideology they carry. This attitude is at the same time coupled with the suppression of the truth of the other systems that will be replaced. In social movements, faith or philosophy of program correctness is often combined with new ways of achieving in the name of ideals like "democracy" or "humanitarian" (Azra, 1996) ${ }^{5}$. In such conditions, the dialectic of violence and anti - violence experienced tremendous shocks. Tension between thesis and antithesis in the dialectic peaked.

In religious context, it seems that the term "radicalism" has not seen eye to eye until now concerning the precise term to describe radical movements ${ }^{6}$. Oliver Roy in his book The Failure of Islamic Politics (Roy, 1994) stated "Islamic movements which orients to the treatment of Islamic law are as fundamental Islam, which is referred with the movements of Ikhwanul Muslimin, Hizbut Tahrir, Jami'ati Islami dan Islamic Salvation Front (IFS) (Roy, 1994).John L. Esposito would prefer to use the term Islamic revivalism or Islamic activism, which has roots in Islamic tradition (Esposito, 1992). In the meantime. Muhammad Abid Al-Jabiri uses the term Islamic extremism. Extreme Islamist groups usually direct the hostility and opposition to "middle" or "moderate" Islamic movements. Therefore, Al-Jabiri said that the true enemy of Islam is an extreme moderate Islam. Al-Jabiri shows the difference of the extreme Islamic movement in this contemporary era. Extremist movements of the past practice of extremism on the order of belief, while extreme movements of contemporary Islamic studies by running it against moderate sects (Al-Jabiri, 2001).

To further clarify the phenomenon of religious radicalism, the framework provided the sociologist of religion, Martin e. Marty, with some modifications, presumably quite relevant applied to see symptoms of "violence in the name of religion". According to him, the main feature is the oppositionalism (understand resistance), i.e. understand resistance to threats that endanger the existence of the religion is viewed, whether in the form of modernity or modernism, secularization, and Western values in General (Azra, 1996).

The fight or struggle attitude is done, including by fighting back groups that threaten the existence or identity of a structure of life; struggling to uphold the ideals that covers general problems of life, such as family or institution social; struggling with (fight with) framework specific value or identity stemming from the legacy of the past as well as new construction; fight (fight against) certain enemies that appear in the form of community or religious social order is considered deviant, and last, they do so within the framework of the struggle on behalf of the (fight under) God (Effendi \& Prasetyo, 1998).

In this regard, the organizations-Islamic organizations that opposed the construction of a number of houses of worship of Christians in most areas of the County, such as Bekasi Islamic Students (PII), the Indonesian Islamic Youth Movement (GPII), the Islamic Defenders Front (FPI), Front Hizbullah, Communications Forum BetweenIndonesian mosques (FORKAMI) and mosque juvenile bonds existing in the entire District of Bekasi, have characteristics put forward by Marty. The first, against a threat that is endangering the existence of the religion, such as industrialization, which is

\footnotetext{
5 In this context, according to Hassan Hanafi, violence occurs in certain environments when he became the only way and the media to express human existence. Violence begins from a situation that is formed by three elements. First, deep feelings of individuals, groups and nations of injustice and despair, secondly, the powerlessness of individuals, groups and communities in changing injustice through non-violent means everything; Third, the lack of dialogue between the perpetrators and the victims of injustice, or maybe there is but a dialogue pseudo (mute). View Hassan Hanafi p. 54 (Hanafi, 2001).

6Many scientists who equate religious radicalism with fundamentalism (ushûliyyûn), "the Islamist" (islâmiyyûn), "the authentic or original" (ashliyyûn), "primary followers of the companions (salafiyyûn)," militant "or even" neofundamentalism ", because it has a certain likeness likeness that resembles the traits in radicalism (Azra, 1996).
} 
considered to have a hidden agenda for the Christianization mission implement. Second, fight back groups which threaten the existence or identity of the life order, in this case, local government policy on the construction of houses of worship and among foreign investors. This is related to the existence of the alleged political engineering of a certain major political party and security apparatus; contrary to the Joint Decree (LCS) are two of the requirements that govern the Minister of construction of houses of worship has at least the head of the household $(\mathrm{HH})$ by as much as $75 \mathrm{KK}$;; infringement building permits (IMB). Third, strive to uphold the ideals that covers general problems of life, such as family or social institutions through the institutionalization of social re-organization "paramilitary", such as the Association of Regional Poetra (IKAPOED) and Unity of Betawi (POB), as a "gang of thugs" who serves as a pressure group. Fourth, struggling to frame a particular value or identity stemming from the legacy of the past and the new construction. Fifth, fight against certain enemies that appear in the form of community or religious society that are considered deviant. This is done to resist groups that are more moderate in view and observe this issue. And sixth, they do so within the framework of the struggle on behalf of God. With the spirit of the less based on the comprehensive understanding of Islam as kaffah doctrine, they often use violent ways to care for and on behalf of purifying Islam from any kinds of deviation among Muslims themselves and attacks from other religions.

Pictures 1

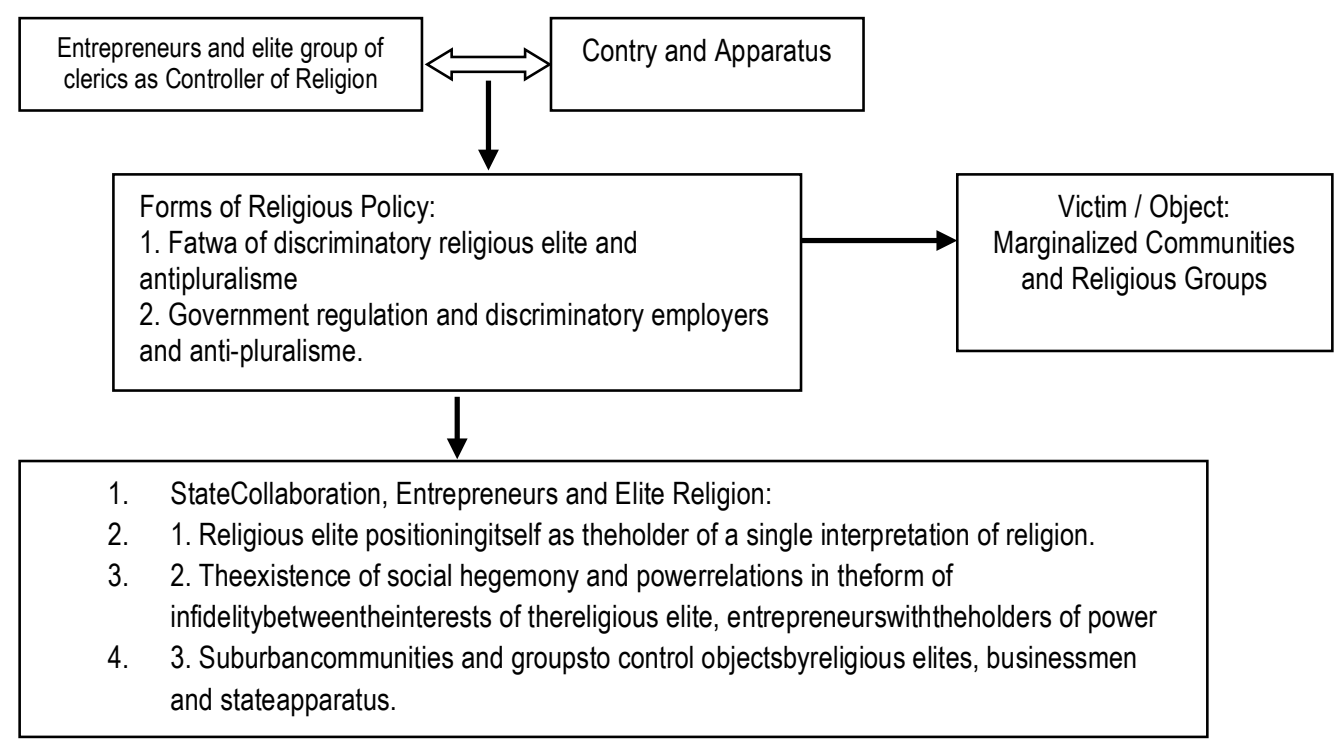

\section{CONCLUSION}

As a strong area which holds religious values, Bekasi district has run religious nuances for personnel's in conducting good governance and not corruptive in designing and implementing services, community development, arrangement and construction of public facilities. Suppression of religious values in all aspects of development is evident in the 7 (seven) Bekasi missions, one of which is "Increasing the role of religious Institutions in development in all fields".

This is evident from the number of Muslim population in Bekasi in 2009, amounting to $1,949,913$ out of a total population of 2.6 million. With a total of seven giant industrial areas, Bekasi district is the state capital buffer area that is undergoing rapid change of the pattern of life of agrarian society to an industrial society. Even this change was to make the area a crucible of various ethnic races and religions. In religious culture, the reality of religious society known as the community holds a strong religious values. Religious traditions such as the routine recitation, Assembly ta'lim, 
religious discourses, tahlil, blessings and ratiban, remain held as religious values that have been running for a long time. Even today, the traditionally-institutionalized religious education in boarding schools still exist with a number of 39 boarding schools, and improved means of actualizing the Muslims over the last two years, the number of mosques has increased by $9.9 \%$, the number of Assembly ta'lim increased $9.7 \%$, and the number of pilgrims increased by $62 \%$.

In the religious life, Bekasi District is known as the life of a religious community. Bekasi Regency worship facility comprised 1,136 mosques, 348 small mosques, langgar 2,216, 16 churches, puree 3 , and 2 monasteries (found in Sukaraya Village District and Village Cibarusah Karang bahagia Cibarusah City District), while there are 3 piecesof monastery (village Babelan City district. Babelan, Karangasih Village district. Cikarang Kedung waringin Northern and Rural district. Kedung waringin).

Quantitatively, Muslims in Bekasidistrict indeed increased religious facilities. Even the number of pilgrims from Bekasi district is increasing from year to year. According to H. Djaelani Salah, S. Ag., (General Secretary of the Bekasi Regency and NU General Chairman Youth Anshor Bekasi), an increase in the quantity of places of worship and pilgrims seem less coupled with improved quality of religious understanding. In fact, not infrequently, increasing means of worship and pilgrims is also predisposed to "reduce" Islamic values. Islam means rahmatan lil 'Alamin, not been fulfilled in life.

In the same context, this condition was not far away with an understanding of pluralism or interreligious harmony. Based on a questionnaire distributed to a number of areas in the community (urban 60 ) and (40 rural people), nearly $82 \%$ knew about the intent for the purpose of interreligious harmony. While $20 \%$ did not know.

In view of the $\mathrm{KH}$. Imam Al-Budry Mulyana, Bekasi Regency society is a society that is very tolerant in religion. Historically, societies have been taught and lived side by side with non-Muslim circles, especially Buddhists and Hindus. According to him, the tolerance can only run if:

a. Among the religions with adherents of other faiths respectand appreciate to each other.

b. Respect the laws and regulations governing the development of the means of Worship

But ironically, the industry seems to be less instrumental in building inter-religious harmony in the society. Corporate Responsibility Fund has not run optimally in building community empowerment much less build togetherness with the surrounding environment. In fact, as mandated by law, the company or the elite residential area should be responsible for the empowerment of local communities. It is revealed that almost $80.36 \%$ did not know the existence of CSR, $8.34 \%$ never feel the benefits of CSR in the form of construction of school infrastructure, and $0.99 \%$ never. 


\section{References}

Al-Jabiri, M. A. (2001). Agama, Negara dan Penerapan Syariah. (Mujiburrahman, Trans.). Yogyakarta: Fajar Pustaka.

Azra, A. (1996). Pergolakan Politik Islam: Dari Fundamentalisme, Modernisme hingga Postmodernisme. Jakarta: Paramadina.

Badan Pusat Statistik (BPS) Kabupaten Bekasi. (2001). Data Statistik Kabupaten Bekasi Tahun 2001.

Banawiratma, J. B. (1993). Bersama Saudara-Saudari Beriman Lain: Perspektif Gereja Katolik. In E. Sarapung, N. Agoeng, \& A. B. Jogoena (Eds.), Dialog: Kritik dan Identitas Agama. Yogyakarta: Dian Interfidei.

Effendi, B., \& Prasetyo, H. (1998). Radikalisme Agama. Jakarta: PPIM-IAIN.

Effendi, B., \& Prasetyo, H. (2000). Repolitisasi Islam: Pernahkah Islam Berhenti Berpolitik?. Bandung: Mizan.

Esposito, J. L. (1992). The Islamic Threat Myth or Reality?. oxford: OxfordUniversity Press.

Hanafi, H. (2001). Agama, Kekerasan dan Islam Kontemporer. (A. Najib, Trans.). Yogyakarta: Jendela.

Hidayat, K. (1998). Tragedi Raja Midas: Moralitas Agama dan Krisis Modernisme. Jakarta: Paramadina.

Mulyana, W. K. (2000). Analisis Sosial tentang Kerusuhan Massa Kasus Pemilu 1997. In Kekerasan dalam Perspektif Pesantren. Jakarta: Grasindo-P3M.

Munawar-Rachman, B. (2006). Ensiklopedi Nurcholish Madjid (Vol. I). Jakarta: Paramadina-MizanCSL.

Pruitt, D. G., \& Rubin, J. Z. (2004). Teori Konflik Sosial. (H. P. Soetjipto \& S. M. Soetjipto, Trans.). Yogyakarta: Pustaka Pelajar.

Roy, O. (1994). The Failure of Political Islam. London: I.B. Tauris \& Co. Ltd.

Sarapung, E., Agoeng, N., \& Jogoena, A. B. (Eds.). (1993). Dialog: Kritik dan Identitas Agama. Yogyakarta: Dian Interfidei.

Tebba, S. (2001). Islam Pasca Orde Baru. Yogyakarta: Tiara Wacana. 